\title{
Vocal cord cavernous hemangioma
}

\author{
Vokal kord kavernöz hemanjiyomu
}

\author{
Nergis Salman, ${ }^{1}$ Muharrem Dağll, ${ }^{2}$ Esma Altan, ${ }^{2}$ Ata Türker Arıkök, ${ }^{3}$ Ali Güvey, ${ }^{2}$ Gökhan Kuran, ${ }^{2}$ Akif Güneşs \\ ${ }^{1}$ Department of Otolaryngology, Ankara Children's Hematology and Oncology Training and Research Hospital, Ankara, Turkey \\ ${ }^{2}$ Department of Otolaryngology, Dışkapı Yıldırım Beyazıt Training and Research Hospital, Ankara, Turkey \\ ${ }^{3}$ Department of Pathology, Dışkapı Yıldırım Beyazıt Training and Research Hospital, Ankara, Turkey
}

\begin{abstract}
Hemangiomas are benign tumors of an unknown etiology which arise from vascular tissues and are mostly seen in the head and neck region. Laryngeal hemangiomas are often seen during childhood and are rarely seen in adults. They are usually located at the subglottic region and cause shortness of breath and a stridor. Laryngeal hemangiomas can be seen in different localizations such as the epiglottis, aryepiglottic fold, arytenoids, ventricular band and the vocal cords. In this article, we present a 50 -year-old male with a cavernous hemangioma located on the free edge of the right vocal cord who was consulted in our clinic with the complaints of persistent voice hoarseness for approximately six-seven months.
\end{abstract}

Key Words: Yetişkin; cavernous hemangioma; vocal cord.

Hemangiomas are common benign tumors of the head and neck region. ${ }^{[1]}$ They are located at the parotid gland, larynx, and tongue of the head and neck region in children. Laryngeal hemangiomas are divided into two groups: adult and infantile. The infantile type is often localized at the subglottic region of the larynx. Stridor and shortness of breath are the most common symptoms in these cases. ${ }^{[2]}$ While a laryngeal hemangioma is rare in adults, vocal cord localization is even rarer. ${ }^{[3,4]}$ Laryngeal hemangiomas localized to the vocal cord frequently present with hoarseness and rarely with shortness of breath. ${ }^{[5]}$ For the adult type, etiological factors of laryngeal hemangiomas are smoking, alcohol consumption, poor use of voice and laryngeal trauma. ${ }^{[3,5]}$ Surgical intervention is usually not necessary for the infantile type, as this kind of hemangioma
Hemanjiyomlar etyolojisi bilinmeyen vasküler dokulardan kaynaklanan ve en sık baş boyun bölgesinde görülen benign tümörlerdir. Larengeal hemanjiyomlar, sıklıkla çocukluk çağında görülmekle birlikte, yetişkinlerde nadir görülür. Genellikle subglottik bölgede yerleşir ve solunum sıkıntısı ve stridora neden olur. Larengeal hemanjiyomlar epiglot, ariepiglottik kat, aritenoidler, band ventriküller ve vokal kord gibi farklı yerleşim yerlerinde görülebilir. Bu yazıda kliniğimize altı yedi aydır devam eden ses kısıklığ yakınmasıyla başvuran, sağ vokal kord serbest kenar yerleşimli kavernöz hemanjiyomu olan 50 yaşında erkek bir olgu sunuldu.

Anahtar Sözcükler: Adult; kavernöz hemanjiyom; vokal kord.

typically spontaneously resolves in two years. Surgical intervention, however, is usually necessary for the adult type. ${ }^{[5]}$ In the case described here, the patient presented with an adult type of cavernous hemangioma located at the anterior third of the right vocal cord.

\section{CASE REPORT}

A 50-year-old male consulted with a major complaint of persistent hoarseness lasting six to seven months, without any other symptoms. He had a smoking history of six packs per year until he was 40 years old. There was no history of alcohol consumption, poor use of voice, or reflux symptoms. The patient had a history of intubation that occurred 18 years prior to admission. The epiglottis, vallecula, bilateral 


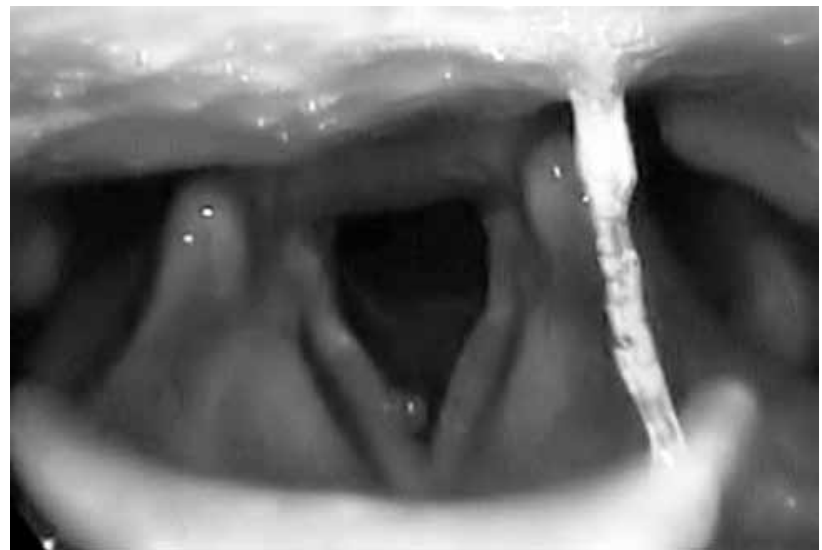

Figure 1. Appearance of the laryngeal polypoid lesion.

pyriform sinuses, ventricular band and left vocal cord were all observed to be normal. A polypoid lesion with a smooth mucosal surface, wide base and a redpurplish color was observed at the anterior third of the medial contact surface on the right vocal cord (Figure 1).

Direct laryngoscopy was performed under general anesthesia. The polyploid lesion was totally removed by microlaryngoscopic technique. A small amount of bleeding was controlled by cottonoids with $1 / 50000$ concentration of adrenaline. No other problem developed during the surgical intervention and the patient was discharged on the first postoperative day. The result of the histopathologic evaluation showed a cavernous hemangioma (Figure 2).

The hoarseness improved over the following nine months, and the views and movements of the vocal cords were observed to be normal by laryngoscopic examination (Figure 3).

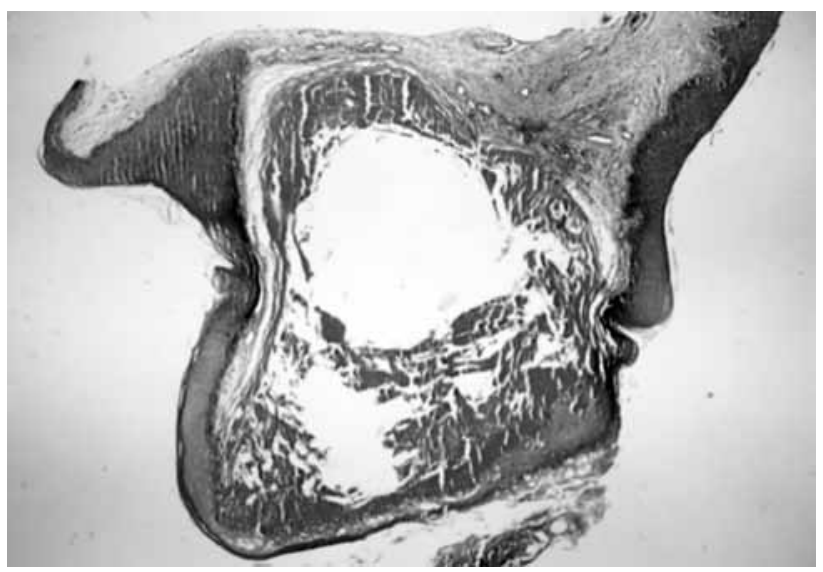

Figure 2. Wide vessel structures were present and filled with blood under the epithelium in the tissue covered with multi-layered flat epithelium (H-E x 10).

\section{DISCUSSION}

Laryngeal hemangioma is rarely seen in adults. In childhood, it is more frequently seen in females whereas and in adulthood, among males. The etiology of laryngeal hemangiomas includes misuse of the voice, smoking and laryngeal trauma. Clear etiological factors were not present in the case described here. Laryngeal hemangiomas are frequently located subglottically in children but localization can differ in adults. Vocal cord hemangiomas are generally found on free edges. ${ }^{[6]}$ In this case, the lesion was located on the anterior third of the free edge of the medial surface of the right vocal cord. Laryngeal hemangiomas are usually of the cavernous type. These lesions are covered with thin mucosa, have a blue-purple color and an irregular surface. ${ }^{[7]}$ Systemic steroids, carbon dioxide $\left(\mathrm{CO}_{2}\right)$ laser excision, microlaryngoscopic techniques and radiotherapy are among the treatment alternatives for hemangiomas. ${ }^{[3,8,9]}$ Despite the treatments available, there is still no general consensus on the treatment process for hemangiomas. The age of the patient, type of lesion, as well as the size and localization of the hemangioma can determine which treatment option is best. ${ }^{[10]}$ Tracheostomy may be required when dealing with large lesions due to the bleeding risk associated with them. ${ }^{[3,8,9]}$ Microlaryngoscopic excision techniques and $\mathrm{CO}_{2}$ laser excision can be performed on small lesions with confidence. ${ }^{[5,9]} \mathrm{We}$ performed microlaryngoscopic lesion excision with direct laryngoscopy in this case.

In conclusion the observation of a hemangioma on a vocal cord is a rare situation and typically presents with voice hoarseness. However, it is important to remember that the color of the hemangioma changes to blue when a polypoid lesion is present in patients with a vocal cord mass. Microlaryngoscopic surgical

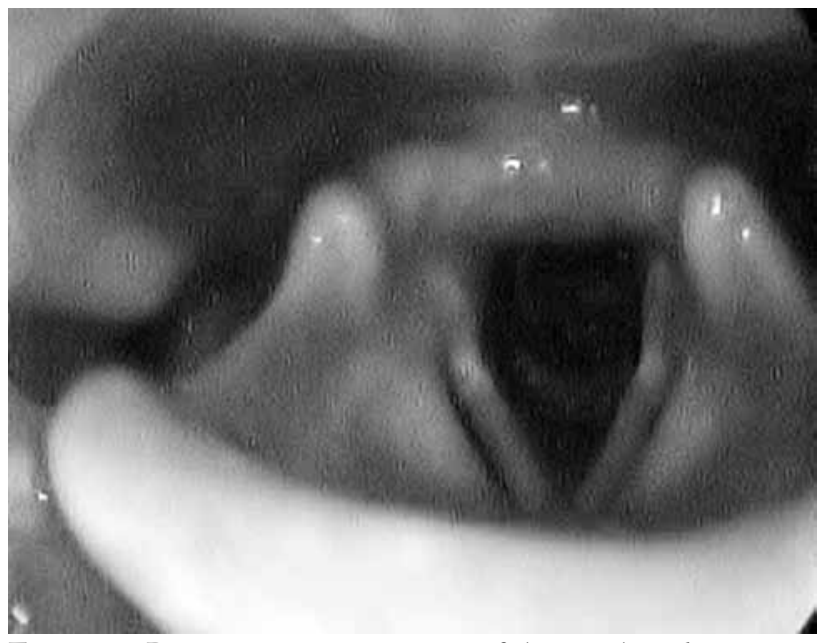

Figure 3. Postoperative appearance of the vocal cords. 
excision is sufficient for treatment of these laryngeal hemangiomas.

\section{Declaration of conflicting interests}

The authors declared no conflicts of interest with respect to the authorship and/or publication of this article.

\section{Funding}

The authors received no financial support for the research and/or authorship of this article.

\section{REFERENCES}

1. Shpitzer T, Noyek AM, Witterick I, Kassel T, Ichise M, Gullane $\mathrm{P}$, et al. Noncutaneous cavernous hemangiomas of the head and neck. Am J Otolaryngol 1997;18:367-74.

2. Kawakami M, Hayashi I, Yoshimura K, Ichihara K, Nishikawa S, Ichihara T. Adult giant hemangioma of the larynx: a case report. Auris Nasus Larynx 2006;33:479-82.
3. Kimmelman CP, Sugar JO, Lowry LD. Resident's page. Pathologic quiz case 2. Hemangioma of the vocal cord. Arch Otolaryngol 1979;105:500-2.

4. Prasad SC, Prasad KC, Bhat J. Vocal cord hemangioma. Med J Malaysia 2008;63:419-20.

5. Lomeo P, McDonald J, Finneman J. Adult laryngeal hemangioma: report of four cases. Ear Nose Throat J 2000;79:594.

6. Shpitzer T, Noyek AM, Witterick I, Kassel T, Ichise M, Gullane $\mathrm{P}$, et al. Noncutaneous cavernous hemangiomas of the head and neck. Am J Otolaryngol 1997;18:367-74.

7. Bastian WR. Benign saccular and mucosal disorders; benign laryngeal tumors. In: Cummings WC, editor. Otolaryngology and head and neck surgery. St Louis: Mosby Yearbook; 1993. p. 1897-923.

8. Sataloff RT, Spiegel JR, Rosen DC, Hawkshaw MJ. Capillary hemangioma of the vocal cord. Ear Nose Throat J 1995;74:390.

9. Bielamowicz S, Stager S, Soofer S. Vocal fold hemangioma. Ear Nose Throat J 2000;79:230.

10. Berkes B, Sente M. Adult laryngeal hemangioma. Med Pregl;51:547-50. [Abstract] 